\title{
NA DESPEDIDA DE ROGER BASTIDE (1)
}

Fernando de Azevedo

Lembra-me ter lido em Haya de la Torre que, em conversa com um alto chefe da Marinha norte-americana, por volta de 1927, o ouvira dizer que não conhecia povo mais inclinado à fácil crueldade do que os latino-americanos. Pouco tempo depois, ao que nos relata, um sábio alemão que veio a conhecer, emitia numa entrevista pessoal a mesma opinião. Goldschmidt (era esse o professor a que se referia, autor de importante obra sobre a América) contou que, indo certa vez à casa de um escritor sul-americano, se espantará de ver os que ali encontrou, tão cruéis, no sentido de falta de respeito e de generosidade uns para com os outros. "Não imagina o sr. a minha desilusão. 0 escritor que me acolheu, não fazia senão falar mal dos demais e de tal forma se pôs a atacar pessoas ausentes que eu considerava dignas de respeito que tratei logo de pôr termo d̀ visita" "Os senhores (acrescentou no encontro com o escritor peruano) não respeitam nada nos outros. Só os mortos se salvam na América Latina"; e passou a explicar, por essa crueldade entre os vivos, "o nosso culto exagerado pelos mortos, a beleza dos cemitérios, a falta de sentido crítico para julgar a obra dos que se foram. Enquanto vivos, a crueldade os destroça, e quando morrem, a superstição os respeita". Embora essa crueldade não a tivesse notado em relação ao estrangeiro a quem, ao contrário, segundo ele, se devotava antes excessiva submissão, declarava Goldschmidt que não quereria ser um latino-americano desses tempos e que seria sempre penosa a sorte de homens superiores estranhos ao ambiente.

No trabalho que publicou, sobre a América, examina o escritor com agudeza e erudiçáo germânica os ditos irreverentes, o rumor malévolo que circula como língua de fogo, o trocadilho ou a anedota que fere como punhal, e o nosso pró. prio chiste ou gracejo, em que vê outras tantas expressōes dessa crueldade que atribui à instabilidade de nossa organização econômica e social, à nossa insegurança e à deficiência de nossas forças. Os povos, como os indivíduos, débeis e tímidos, são cruéis. E os latinos já diziam: timidus, crudelis. Porque estamos envenena- 
dos de crueldade, de ressentimentos e rancores, os nossos julgamentos são ar.tes cruéis do que severos; e mesmo entre os homens superiores desses países, não faltam, a seu juízo, alguns cuja grandeza é marcada pela crueldade. Dia virá, forém (e já é o seu, um prognóstico animador), em que a fortaleza nos faça generosos uns para com os outros e muita energia que se perde ou se desperdiça, se utilizará nas grande realizações. É possível que, descontados os exageros, ainda fique um resíduo de muita verdade nas observaçóes do almirante americano e do sábio alemạio. Mas acredito que, se tivesse qualquer deles visitado um desses grupos literários, - as "chapelles" como lhes chamais, ou as "igrejinhas" como por aqui são batizados, teriam eles sentido a necessidade de rever os seus julgamentos diante da doçura com que se entendem, dos louvores com que se obsequiam e da indulgente admiração que, no interior do grupo, se consagram uns aos outros e é só comparável à hostilidade com que encaram os estranhos a essas confrarias. $\mathrm{Na}$ série de retratos de animais, que Jules Renard reuniu em suas "Históires Naturelles", um dos mais finos e espirituosos é o dos pombos. "Les Pigeons", de que o observador incisivo nos dá, com alguns traços essenciais, uma pintura graciosa, ironica e fiel. Os escritores e os poetas (ah! se Goldschmidt os tivesse surpreendido nos seus ćrculos de camaradagem e nessas feiras de vaidades satisfeitas!) fazem-se, como os pombos, as resmas saudações frenéticas, "encantam, como eles, a princípio e acabam por entediar", e, nos louvores que se trocam, de boca a boca, julgam poderem fecundar-se uns aos outros e produzir criações originais, como os pombos que, fazendo sobre as casas "um ruído de tambor velado", se obstinam, com seus arrulhos, "à croire qu'on fait les enfants par le bec"...

De vossa passagem pela nossa Faculdade, não nos terá ficado, Prof. Roger Bastide, nem ura nem outra impressão: nem a de hostilidades e prevenções, nem a das complacências e cumplicidades de situações de compromisso. Nem a de crueldade de competiçōes desabridas nem a de efusōes sentimentais das "coteries". Naquele ambiente, em que, para nosso prazer e proveito, trabalhastes conosco dezoito anos, em que há um pouco de nós, sul-americanos do Brasil, ficou muito da missão francesa, e, particularmente de vós. Foi certamente larga a contribuição que trouxeste, para recrí-la, fazendo circular pela atmosfera do Departamento não só a consciência da necessiḍade de uma disciplina ascética nos estudos, o gosto da pesquisa e da descoberta, o espírito crítico e o juízo pessoal, senão também o sentido de responsabilidade como o de equilíbrio e de medida, a liberdade e a exatidão de julgamentos (e nós, em geral, não somos severos porque somos injustos, e, por isso mesmo, cruéis), uma inteligencia, compreensiva e humana, mas que aprendeu a distinguir, na hierarquia de valores, os merecimentos autênticos e, além da modéstia, um certo sentido de humildade que provém dessa comparação constante entre o pouco que, afinal, sabemos e o muito que ainda nos resta conhecer. Tudo isso faz parte do espírito da cultura francesa e de tal modo e em tão alto grau já vinha integrado em vós, que, se, por vossos exemplos e lições, não tivésseis repartido, em graus variáveis, por tantos de vossos discípulos, teríamos de convocar-vos e reunir-nos não para um jantar de despedida, mas para vos declarar e vos conservar nosso prisioneiro, mas sem a mais vaga intenção de envolver-vos um dia (e preciso ter muito cuidado com a crueldade sul-americana. ..) numa dessas cerimônias antropofágicas em que certas sociedades primi- 
tivas acabavam por devorar os prisioneiros, na crença de ingerirem, com a carne humana, as suas mais apreciadas qualidades. ..

No Departamento de Sociologia e Antropologia, em nome do qual tenho a honra de vos falar, não fostes apenas o sociólogo eminente que, ao chegar no Brasil, ainda moço, já se havia imposto nos meios europeus, pelos seus estudos sobre a vida mística e a sociologia religiosa, e cuja presença sentimós logo, aos primeiros contatos, por seu saber e por sua erudiçãc. Fostes ainda (o que era da maior inıportáncia para nós) um conselheiro, modelo e gưia, o homem de ciência que escolhera e realizou, dentre "as maneiras de ser um sábio" que Charles Richet analisou, a mais bela, a mais humana e a mais fecunda: a do professor que, sendo um cientista e pesquisador de prirreira ordem, "se compraz em se ver cercado de seus alunos, em lhes abrir perspectivas e indicar-lhes o trabalho a fazer; que conversa com eles; que os faz partilhar suas idéias; lhes dá conselhos; que é feliz quando pode traçar um plano de pesquisa; que passa de boa vontade horas com seus alunos para lhes inspirar trabalhos que thes são tẫc caros como os seus próprios; que faz escola" e deixa discípulos. Já podeis compreender agora, meu caro Prof. Bastide, que, embora tenhamos a segurança de vos rever entre nós e de tornar a vos ouvir, a curtos intervalos, não podemos deixar de sentir a tristeza de perder professor de tão alta categoria, que tão poderosamente concorreu para o desenvolvimento dos estudos e das pesquisas sociologicas entre nós; o homem que sempre se conduziu nobremente, sem o querer, por estar acostumado a não querer nada dos outros e a servi-los sempre; um dos maiores e melhores amigos do Brasil - a vossa segunda pátria, pelos serviços que prestastes à cultura e a formação da mocidade, pela obstinação metódica e pelo calor humano que com que lhe estudastes, através de anos, a cultura literária e artística e aspectos da vida e organização social, em uma série inumerável de pesquisas, trabalhos e obras; e, sobretudo, o amigo e companheiro de todas as horas, cujas convivência e colaboração inestimáveis, com se terem estendido por dezoito anos, ainda nos parecem curtas demais para nossos desejcs e necessidades, mas foram suficientemente longas para criarem, entre nós, uma dessas amizades superiores a todas as contigências e nos assegurarem, em nossos estudos, no ensino e nas atividades cientificas, a presença constante de vosso alto espŕrito, de vossas sábias lições e de vosso grarde e generoso coração. 